\title{
İşletmelerin Etik Dışı Davranışlarının Tüketiciler Tarafından Değerlendirilmesine Yönelik Bir Alan Araştırması
}

DOI: $10.26466 /$ opus.763786

$*$

\section{Yakup Güzel *}

${ }^{*}$ Dr. Hacettepe Üniversitesi İ.I.I.̇.B.F. Aile ve Tüketici Bilimleri Bölümü E-Posta: yakup.guzel@hotmail.com

ORCID: 0000-0003-4641-480X

\section{Öz}

İs etiğgi ile ilgili çalışmaları incelediğimizde genelde iş etiğinin işletmelerin iç meselesi gibi algılandığı, bu nedenle işletmede çalışanların iş etiğiyle ilgili algılarına yönelik çalışmalara ă̆ırlık verildiği görülmektedir. Oysaki iş etiği işletmenin imajıyla doğrudan alakalı bir husus olup özellikle işletmelerin paydaşları açısından önem teşkil etmektedir. İşletmenin en önemli paydaşlarından birisi de tüketicilerdir ve tüketici açısından işletmenin veya markanın dürüstlü̆̆̈̈ ve güvenilirliği oldukça önemlidir. İşletme tüketici ilişkisi açısından ele aldı ̆̆ımızda yapılan çalışmaların daha çok iş etiği ve tüketici etiği üzerine olduğunu görmekteyiz. İş etiğinin tüketici davranışlarına olan etkisine ve işletme tüketici ilişkilerinde etik standartlara yönelik kapsamlı bir çalışmaya ihtiyaç vardır. Bu kapsamda tüketiciye mal ve hizmet satan işletmelerdeki etik dışı davranışların tüketiciler tarafından nasıl değerlendirildiğinin tespiti amačyla araştırmada, Ankara'da yaşayan 18 yaş üstü tüketicilerin işletmelerle ilgili şikâyetlerinin tüketici algısındaki etik değerlendirmeleri Aralık 2019'da gerçekleştirilen bir alan araştırması ile incelenmeye çalışılmıştır. Her bir şikâyet ve bunun sıklık yüzdesi yapılan saha araştırmasından elde edilen verilerle sağlanmıştır. Bu şikâyetlerin etik değerlendirmeleri de tüketicilere sorularak ortaya çıkarılmaya çalışılmıştır. Bu şekilde işletmelerin müşteri memnuniyeti açısından dikkat etmesi gereken hususlar ortaya çıkarılabilecektir.

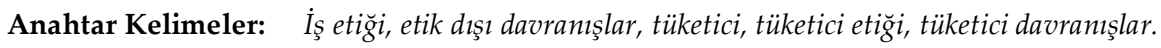


ISSN: 2528-9527

E-ISSN : 2528-9535

Yıl Year: 11

Cilt Volume: 17

Sayı Issue: 35

Mart March 2021

Makalenin Geliș Tarihi Received Date. 03/07/2020

Makalenin Kabul Tarihi Accepted Date. 29/03/2021

\title{
A Field Study on Consumers' Evaluations About Businesses'Unethical Behaviors
}

\begin{abstract}
When the studies related to work ethics are reviewed, it is seen that work ethic is perceived as internal matter of businesses in general; therefore, it is more focused on work ethics of the personnel in that businesses. However, work ethics is directly related to corporate image of business and especially have importance with regards to businesses' stakeholders. One of them most important stakeholders of business is consumer and in terms of consumer to what degree honesty and reliability of business or brand is important? When we consider the relationship between business and consumer, we realize that studies are more on work ethics and consumer ethic. There is need for a comprehensive work towards the impact of work ethics on consumer behavior and ethic standards within business-consumer relations.

In this scope, with the aim of identifying that how unethical behaviors in businesses providing goods and services to consumers are evaluated by consumers, in the study, the ethical evaluation of complaints of consumers over the 18 age and residing in Ankara, in consumer perception are examined as field research in December 2019. Each and every complaint and their frequency rates are obtained from field research data. The ethical evaluation of that complaints are also tried to be uncovered through asking to consumers. In this way, with regards to customer satisfcation which type of behaviors that businesses need to avoid could be find out.
\end{abstract}

Keywords: Work ethics, unethical behaviors, consumer, consumer ethic, consumer behaviors 


\section{Giriş}

İş etiği günümüz ticari hayatının en önemli unsurlarından birisidir. İş etiğinin olmadığ1 veya eksik olduğu ticari hayatta güven unsuru ortadan kalkacağından ticaret yapmakta oldukça zorlaşacaktır. Herkesin birbirine kuşkuyla baktığı ve karşılıklı güvenin olmadığı bir ortamda ticari ilişkiler ister istemez olumsuz etkilenecektir. Tacirler birbiriyle veya tüketicilerle alışveriş yaparken acaba aldatıldık mı, aldığımız üründe herhangi bir hile var mı, malın bedelini tahsil edebilir miyim veya ödemeler zamanında gerçekleştirilir mi? Kredi kartı bilgilerim çalınır mı? Gibi sorular yüzünden alışveriş yapmaktan kaçınacak bu da ister istemez talebi düşürecek veya daha dürüst işletmelere yönlendirecektir. Özellikle iş etiğiyle tüketici davranışları arasında doğrudan bir ilişki olduğu varsayılmaktadır.

Gerek iç piyasada gerekse uluslararası piyasalarda çok ciddi bir rekabet ortamı vardır. Sunulan mal ve hizmetlerin kalitesi ve fiyatları birbirine yakın olduğu için ticaret piyasalarında talebi etkileyen diğer hususlar önem kazanmaktadır. Bu hususların başında ise ticaret yapılan ülkeye, firmaya ve mala olan güven ve dürüst ticaret konusu öne çıkmaktadır. Ticaretin dürüstçe yapılabilmesi için bazı ülkelerde özel olarak kamu kurumları bile kurulmuştur. İngiltere'deki Adil Ticaret Ofisi (Office of Fair Trading-OFT) bunun en güzel örneklerinden birisidir. (https://www.gov.uk/government/organisations/office-of-fair-trading)

Rekabetin son derece yoğun olduğu ülkemiz ticaret hayatında firmaların başarılı ve kalıcı olabilmesinin yollarından birisi hedef kitle olan müşterilerin firmayı tercih etmesinden geçmektedir. Müşterilerin tercihlerini etkileyen birçok faktör olmakla birlikte bu faktörler arasında yer alan işletmelerdeki etik dışı hususların tüketici açısından nasıl karşılandığının ve algılandığının tespiti büyük önem arz etmektedir. Zira tüketici açısından hoş karşılanmayan etik dışı davranışlardan kaçınmak işletmenin tercih edilirliğini arttıracaktır.

Bütün pazarlama karar ve durumlarının ahlaki değerler, standartlar ve kurallar kapsamında, yeniden değerlendirilmesi ve revize edilmesi pazarlama etiğinin temel amacını oluşturmaktadır.

Özdoğan (2006) tarafından yapılan bir araştırmada, yer alan iki modelle ilgili tüketicinin etik hassasiyetinin, algıladığı sosyal baskının ve zarar seviyesinin işletmenin etik dışı davranışını olumsuz değerlendirme ihtimalini 
yükselttiği; tüketicinin işletmeye olan sadakatinin işletmenin etik dişı davranışını negatif şekilde değerlendirme ihtimalini azalttığını göstermektedir. Diğer yandan, her iki model için tüketicinin algıladığı sosyal baskı ve algıladığı zararın derecesi ile işletmenin etik dışı davranışını negatif şekilde değerlendirmesinin satı alma niyetini negatif şekilde etkilediği belirtilmiştir. Tüketiciye dolaylı olarak zararın söz konusu olduğu birinci modelde yalnızca bağlılık ve algılanan zararın derecesi değişkenlerinin etkileşimi anlamlı bir etkiye sahipken, tüketiciye doğrudan zararın söz konusu olduğu ikinci modelde ise hem bağlılık ile algılanan zararın derecesi değişkenlerinin etkileşimi, hem de bağlılık ve algılanan sosyal baskı değişkenlerinin etkileşimi anlamlı bir etkiye sahip olduğu bulunmuştur (Özdoğan, 2006, s.370).

$\mathrm{Bu}$ araştırmanın sonuçları tüketicilere mal ve hizmet satan işletmeler açısından rehber niteliğinde olacaktır. Bu araştırmada işletmelerdeki etik anlayışı ile tüketici davranışı arasındaki ilişki talep yönüyle ele alınacaktır. Araştırma sonuçları çerçevesinde etik ile ilgili hususların tüketiciler tarafından nasıl değerlendirildiği ve firmaların hangi davranışlardan kaçınması gerektiğ $i$ açıklanmaya çalışılacaktır.

\section{İş Etiği ve Ahlakı}

Sanayi devrimi öncesi iş ahlakı ve etiği, örf, adet ve dini kurallara dayalı değerler olarak görülmekteydi. Bu süreçte dini değerlerin, çalışma ilişkilerinin, ekonomik sürecin ve iş etiğinin şekillendirilmesinde oldukça önemli etkiye neden olduğu görülmektedir (Osthaus, 2004, s.747).

Serbest piyasa ekonomisine geçişle birlikte iş dünyasında ve toplumda bir yozlaşma ortaya çıkmıştır. Artan yolsuzluk ve hırsızlık vakaları, rüşvet, çete ve mafya olayları bunların en önemli göstergeleridir. Bu tip olayların artışı iş ahlakının önemini ve farkındalığını da arttırmıştır. Günümüzde artık dürüst ticarete olan ihtiyaç her zamankinden daha fazladır.

İş ve meslek ahlakı 1920'lerde ele alınmaya başlanmış ve 1960 ila 1970 arası ciddi bir gelişme göstermiştir. Ancak son yirmi yılda çok önem kazanmıştır. Bu süreçte Journal of Business Ethics and Business $\mathcal{E}$ Professional Ethics gibi bazı yayınlar ortaya çıkmış ve konuyla ilgili çok sayıda konferans ve bilimsel çalışma yapılmış ve oldukça büyük ilgi görmüştür (Vitell and Ho 1997). 
Akbulut (2000), İş ahlakını, belirli bir sektörde işin yapılması ve uygulanması esnasında faydalı olduğu düşünülen kurallar ve davranış biçimleri olarak tanımlamıştır (Akbulut, 2000, s.4) Dolayısıyla iş hayatında dürüst davranma, güven duyma, saygı gösterme ve eşitlikçi bir anlayışla davranma gibi hususlar iş ahlakının unsurlarıdır.

İş ahlakı, genel olarak bakıldığında ahlak bilgisinin uygulamalı yönüdür ve iş yaşamında karşılaşılan bütün ahlaki meseleleri inceler. Bu meseleler, personel arasında, personelle yöneticiler arasında, işletme ve işletmeden alışveriş yapanlar ya da işletmeyle çevresel faktörler arasında olabilir (auzefkitap.istanbul.edu.tr). İş ahlakı aynı zamanda işletmenin insan kaynakları yönetiminde, pazarlama faaliyetlerinde kısacası bütün faaliyetlerinde anahtar rolü oynamaktadır. Bu süreçlerden birinde yaşanacak olan ahlak dışı davranışların işletmenin bütün akışını bozacağı açıktır.

İş etiğiyse, iş hayatındaki mevzuatı, kamusal sorumluluk prensiplerini ve paydaşlarla olan münasebetleri kapsadığı belirtilmekte; insanlara karşı adaletli davranılması ve işletmeyle ilgili olumlu hisler meydana getirecek şekilde davranılması olarak ifade edilmektedir (Blanchard, 2002, s.22-23).

Gök (2008) İş etiği ve iş ahlakının tanımlarından hareket ederek; iş ahlakının, toplumdan topluma değişen, örf, adet, etnik köken ve inanca göre uyulması gereken kurallar bütünü olduğu; iş etiğininse, küresel, dünyadaki herkes için geçerliliği olan, felsefeye ve düşünmeye dayalı davranış ilkelerini kapsadığını belirtmiştir (Gök, 2008, s.9).

\section{İş Etiği veTüketici İlişkisi}

Çağımızın en önemli trendlerinden birisi "Tüketici" olup, refahın altında "Üretim", üretimin altında da "Tüketim" yer almaktadır (Aslan, 2005, s.154). Üretimin nihai hedefi üretilenin tüketilmesi olup tüketimin yani talebin oluşturulamadığı durumlarda işletmenin hayatını devam ettirmesi mümkün değildir.

Tüketici Kanunun temel hedefi güçlü işletmeler karşısında zayıf durumda olan tüketicilerin ekonomik çıkarlarının ve menfaatlerinin korunmasıdır. $\mathrm{Bu}$ çerçevede tüketici; üretim hatalarından, ayıplı mal ve hizmetlerden, aldatıcı ve yanıltıcı reklâmlardan, dürüst olmayan ticari uygulamalardan korunmaktadır. Bu aykırılıklardan özellikle aldatıcı ve yanıltıcı reklamlar ile dürüst olmayan ticari uygulamalar işletmenin etik dışı davranmasının sonucu ortaya çikan uygulamalardır. 
Tüketicilerin öncelikle yerli ürünleri tercih ettikleri, bazı durumlarda ise yerli ürünler yerine yabancı ürünleri tercih ettikleri yapılan araştırmalarda da görülmektedir. Tüketicilerin yerli ürünleri tercih nedenlerindeki değişimlerin sebepleri ise kalite, ürün çeşitleri, fiyat, ülkelerin imajları ve gelişmişlik düzeyleridir (Özçelik ve Torlak, 2011, s. 361-377). Bazen tüketici kendine sayginlık kazandırmak amacıyla da yabancı ürünleri tercih etmektedir (Ettenson ve Gaeth, 1991, s.13-18)

Kurtuluş (2005) Devletin, serbest piyasanın etik ve ahlaki ilkelere uygun hale dönüştürülmesi konusunda düzenlemeler yapması gerektiğini, tüketicilerin ve ticari işletmelerin etik dışı davranan işletmelerden alışveriş yapmamalarını, bu şirketlerin hisse senetlerine yatırım yapmamaların, ahlaki normlara uygun hareket edenleri ise tercih ederek ödüllendirme yoluna gidilmesi gerektiğini bu konuda sivil toplum kuruluşlarına da oldukça önemli görevler düştüğünü öne sürmüştür (Kurtuluş 2005, s.737,759).

Gelişen ve günden güne tüketici odaklı bir hale evrilen modern pazarlamanın en önemli güçlerinden birisi de "Pazarlama Etiği" ve buna paralel planlanması gereken "tüketici ilişkileri" yönetimidir (Güler, 2014, s.65-75). Pazarlama etiğinin tam olarak anlaşılabilmesi açısından tüketicilerin hangi konuları etik dışı bulduğunun araştırılmasının son derece önemli olduğu düşünülmektedir. Bu doğrultuda bu araştırma ile tüketicilerin etik dışı buldukları konular belirlenmeye çalışılmıştır.

\section{Araştırmanın Amacı, Önemi, Yöntemi ve Sınırlılıklanı}

Araştırmada, Ankara'da yaşayan tüketicilerin işletmelerle ilgili şikâyetlerinin tüketici algısındaki etik değerlendirmeleri bir alan araştırması ile incelenmeye çalışılmıştır. Her bir şikâyet ve bunun sıklık yüzdesi yapılan saha araştırmasından elde edilen verilerle sağlanmıştır. Bu şikâyetlerin etik değerlendirmeleri de tüketicilere sorularak ortaya çıkarılmaya çalışılmıştır. Bu şekilde firmaların müşteri memnuniyeti açısından öncelikle hangi davranışlarda kaçınması gerektiği ortaya çıkarılabilecektir.

Anket formu toplam 31 sorudan oluşmakta olup ilk beş soru demografik verilere, ikinci gruptaki 26 soru ise etik algısına ilişkindir. Ankette yer alan sorular Tüketici Hakem heyetlerine ve Ticaret Bakanlığ 1 Alo 175 Tüketici Danışma Hattına gelen şikayetler ve Gıda, Tarım ve Hayvancılık Bakanlığı'nın açıklamış olduğu gıda denetimi sonuçları esas alınarak belirlenmiştir. 
Aralık 2019'da Ankara'da yaşayan 405 tüketiciye tesadüfi örnekleme yöntemi ile ulaşılmış ve likert derecelendirme ölçeği ile bu şikâyetlerin etik dişı olma düzeyleri tespit edilmeye çalışılmış ve sıklık yüzdeleri ile karşılaştırılmıştır. Bu şekilde firmaların hangi etik dışı davranışlardan öncelikli olarak sakınması gerektiği ortaya konmaya çalışılmıştır. İstatistiki olarak \%5 hata oranıyla kullanılacak örneklem yeterli düzeydedir. Araştırmada demografik sorulara da yer verilmiş ve demografik farklılıklara göre firma etik dışı davranışların derecesi karşılaştırılmıştır. Parametrik ve parametrik olmayan testlerle araştırma tamamlanmaya çalışılmıştır.

Araştırma, anketine katılımı sağlanan 405 kişiden oluşan örneklem grubunun verdiğgi cevaplar ile sınırlandırır. Örneklemdeki sınırlılık araştırma evreninin tamamının incelenmesinin olanaksızlığıdır. Katılımcıların doğru, samimi yanıtlar verdiği varsayımı araştırmamızın bir diğer sınırlılı̆̆ıdır. Seçilen örneklem grubunun ana kütleyi/evreni yeterince temsil ettiği ve örneklem üzerinden ana kütleye genelleme yapılabileceği varsayılmıştır.

\section{Araştırma Bulguları ve Temel İstatistiki Analizler}

Tablo 1. Demografik Analizler

\begin{tabular}{llll}
\hline Değişkenler & & $\mathbf{N}$ & \% \\
\hline Cinsiyet & Kadın & 186 & 45,9 \\
& Erkek & 219 & 54,1 \\
& Toplam & 405 & 100,0 \\
\hline Yaş & $18-25$ & 36 & 8,9 \\
& $26-32$ & 141 & 34,8 \\
& $33-40$ & 90 & 22,2 \\
& $41-48$ & 87 & 21,5 \\
& $48+$ & 51 & 12,6 \\
\hline Eğitim Durumu & Toplam & 405 & 100,0 \\
& Ilköğretim & 21 & 5,2 \\
& Lise & 60 & 14,8 \\
& Önlisans & 30 & 7,4 \\
& Lisans & 237 & 58,5 \\
& Lisansüstü & 57 & 14,1 \\
& Toplam & 405 & 100,0 \\
\hline Gelir Durumu & $0-1000$ & 27 & 6,7 \\
& $1001-2000$ & 54 & 13,3 \\
& 2001-3000 & 84 & 20,7 \\
& 3001 ve üzeri & 240 & 59,3 \\
& Toplam & 405 & 100,0 \\
\hline Çalışma Durumu & Emekli & 42 & 10,4 \\
& Kamu Çalışanı & 246 & 60,7 \\
& Özel Sektör Çalısanı & 84 & 20,7 \\
& Serbest & 33 & 8,1 \\
& Toplam & 405 & 100,0 \\
\hline
\end{tabular}


Araştırma sonuçlarına göre, araştırmaya katılanların \%54,1'i erkek, \%45,9 $\mathrm{u}$ ise kadınlardan oluşmaktadır. Araştırmaya katılanların \%8,9 u 18-25 yaş aralığında, \%34,8 i 26-32 yaş aralığında, \%22,2 si 33-40 yaş aralığında, \%21,5 i 41-48 yaşa aralığında, \%12,6 sı ise 48 yaş üzeridir. Eğitim durumuna göre ise katılımcıların \%58,5 i lisans, \%14,8'i lise, \%14,1 lisansüstü, \%7,4 ön lisans, $\% 5,2$ 'si ise ilköğretimdir. Gelir açısından katılımcıların dağılımı ise, $3001 \mathrm{TL}$ ve üzeri geliri olanlar \%59,3, 2001-3000 TL arası geliri olanlar \%20,7, 1001-2000 TL arası geliri olanlar $\% 13,3$ ve $0-1000$ TL arası geliri olanlar ise $\% 6,7$ oranındadır. Araştırmaya katılanların \%60,7'si kamu çalışanlarından, \%20,7'si özel sektör çalışanlarından, \%10,4 ü emeklilerden, \%8,1 i ise serbest çalışanlarından oluşmaktadır. Kamu çalışanlarının yüksek çıkmasının nedeninin Ankara'nın memur şehri olmasından kaynaklandığı düşünülmektedir.

Tablo 2. Şikâyetlere İlişkin Etik Dışı Algı Düzeyi

\begin{tabular}{|c|c|c|c|}
\hline & $\mathrm{N}$ & Ortalama & StandartSapma \\
\hline Satış esnasında satış elamanı tarafından ürünün özelliklerinin eksik anlatılması & 405 & 1,6000 & 70393 \\
\hline Satış esnasında satış elamanı tarafından ürünün özelliklerinin abartılı anlatılması & 405 & 1,5852 & 60329 \\
\hline Tüketiciye saygısız davranılması & 405 & 1,2074 & ,57428 \\
\hline Tüketiciye kötü davranılması & 405 & 1,2370 & 60109 \\
\hline Tüketicinin yasal haklarının kullandırılmaması & 405 & 1,1704 & 49687 \\
\hline Tüketiciye işletme ile ilgili yalan söylenilmesi & 405 & 1,2000 & 47000 \\
\hline Tüketiciye fahiş fiyatla satış yapılması & 405 & 1,3259 & 62090 \\
\hline Satılan malın ayıbının hile ile gizlenmesi & 405 & 1,1407 &, 52066 \\
\hline Tüketiciye bozukürünlerin satılması & 405 & 1,1630 & ,50678 \\
\hline Tüketiciye son kullanım tarihi geçmişürünlerin satılması & 405 & 1,1556 &, 50174 \\
\hline $\begin{array}{l}\text { Et ve et ürünlerinde hile yapılması (\%100 dana eti denilen sucuğun at veya eşek } \\
\text { etinden ya da tavuk ve sakatattan yapılması gibi) }\end{array}$ & 405 & 1,0667 & ,32782 \\
\hline $\begin{array}{l}\text { Gıdada toplumun dini hassasiyetlerine aykırı katkıların kullanılması ve bunun } \\
\text { satış anında bildirilmemesi (domuz jelatini, alkol vb.) }\end{array}$ & 405 & 1,1407 & ,38947 \\
\hline Satılan mallarla ilgili aldatıcı ve yanıltıcı reklam yapılması & 405 & 1,4074 & ,57687 \\
\hline Satılan hizmetlerle ilgili aldatıcı ve yanıltıcı reklam yapılması, & 405 & 1,3926 &, 53387 \\
\hline Para üstünün eksik verilmesi & 405 & 1,3704 &, 58259 \\
\hline Pazarcıların tezgaha güzel ürünleri dizip torbaya kötü ürünleri doldurması & 405 & 1,2889 &, 59684 \\
\hline Göstermelik veya aldatıcı indirimlerle müşteri çekilmeye çalışılması & 405 & 1,6222 & 71097 \\
\hline Ölçü ve tartıda hile yapılması & 405 & 1,1333 & 48561 \\
\hline Daha fazla kar elde etmek için sağlı̆g zararlı ürünler satılması & 405 & 1,1407 &, 50613 \\
\hline Bazı müşterilere ayrıcalıklı davranılması & 405 & 1,9185 & ,90646 \\
\hline $\begin{array}{l}\text { Stoklarda olmayan ürünler varmış gibi davranıp müşteri çekmeye çalışarak } \\
\text { başka ürün satılmaya çalışılması }\end{array}$ & 405 & 1,5778 & 65182 \\
\hline Tüketicinin yanlış ödeme yapması durumunda uyarılmaması & 405 & 1,4148 & 68442 \\
\hline İade kabul edilmemesi & 405 & 1,7111 & 83636 \\
\hline İnsan sağlı̆ı açısından güvenli olmayan ürünlerin satılması & 405 & 1,1333 & 48561 \\
\hline Valid N (listwise) & 405 & & \\
\hline
\end{tabular}




\section{Kesinlikle Etik Değil 5 Kesinlikle Etik}

Tüketiciler açısından en etik dışı bulunan konu 1,0667 ortalama ile Et ve et ürünlerinde hile yapılmasıdır. (\%100 dana eti denilen sucuğun at veya eşek etinden ya da tavuk ve sakatattan yapılması gibi). Bu veri de bize tüketicilerin gida konusunda oldukça hassas olduklarını göstermektedir. Tüketicilerin et ve et ürünlerinde hile yapıldığını tespit etmesi mümkün olmamakla beraber Gıda, Tarım ve Hayvancılık Bakanlığı tarafından bu analizler düzenli olarak yapılmakta ve aykırılık tespit edilen firmalar kamuoyuna ilan edilmektedir (Anadolu Ajansı, 2021). Açıklanan bu listelerin tüketicilerin bilgilenme hakkı açısından da son derece yararlı olduğu ve tüketicileri bu tip firmalara karşı dikkatli olmaya sevketiği düşünülmektedir.

İkinci sırada etik dışı bulunan konu ise 1,1333 oranı ile "İnsan sağlığı açısından güvenli olmayan ürünlerin satılması" ve "Ölçü ve tartıda hile yapılması" çıkmıştır.

Üçüncü sırada etik dışı bulunan hususlar ise 1,1407 oranı ile "Gıdada toplumun dini hassasiyetlerine aykırı katkıların kullanılması ve bunun satış anında bildirilmemesi (domuz jelatini, alkol vb.)" ve "Daha fazla kar elde etmek için sağlığa zararlı ürünler satılması" olarak belirtilmiştir.

Daha az etik dışı bulunana konulara bakacak olursak; ilk sırada 1,9185 oranı ile Bazı müşterilere ayrıcalıklı davranılması gelmektedir. İade kabul edilmemesi de 1,7111 oranı ile daha az etik dışı bulunan konulardan ikinci sırayı almaktadır. Üçüncü sırada ise "Göstermelik veya aldatıcı indirimlerle müşteri çekilmeye çalışılması" gelmektedir.

\section{Faktör Analizi}

Tablo 3. Şikâyetlere ilişkin Etik Algı Düzeyi Faktör Analizi

\begin{tabular}{|c|c|c|c|c|}
\hline Değişkenler & $\begin{array}{l}\text { Faktör } \\
\text { Yükleri }\end{array}$ & $\begin{array}{l}\text { Öz } \\
\text { değer }\end{array}$ & $\begin{array}{l}\text { Açılanan } \\
\text { Varyans \% }\end{array}$ & $\begin{array}{l}\text { Toplam } \\
\text { Varyans \% }\end{array}$ \\
\hline Faktör 1: Satış Esnasında Yaşanılan Sorunlar & & 9,59 & 39,9 & 39,9 \\
\hline Satılan malın ayıbının hile ile gizlenmesi &, 852 & & & \\
\hline Tüketiciye bozukürünlerin satılması, & 839 & & & \\
\hline Tüketiciye son kullanım tarihi geçmiş ürünlerin satılması & 772 & & & \\
\hline Ölçü ve tartıda hile yapılması & 661 & & & \\
\hline Tüketicinin yanlış ödeme yapması durumunda uyarılmaması & ,553 & & & \\
\hline Tüketiciye kötü davranılması &, 549 & & & \\
\hline Para üstünün eksik verilmesi &, 509 & & & \\
\hline $\begin{array}{l}\text { Faktör 2: Tüketicinin Ekonomik Çıkarları, İnancı ve Sağlığı } \\
\text { İle İlgili Sorunlar }\end{array}$ & & 2,15 & 8,9 & 48,9 \\
\hline İnsan sağlığı açısından güvenli olmayan ürünlerin satılması & ,786 & & & \\
\hline Daha fazla kar elde etmek için sağlığa zararlı ürünler satılması. & ,774 & & & \\
\hline
\end{tabular}




\begin{tabular}{|c|c|c|c|c|}
\hline $\begin{array}{l}\text { Gıdada toplumun dini hassasiyetlerine aykın katkıların kullanıl- } \\
\text { ması ve bunun satış anında bildirilmemesi (domuz jelatini, alkol } \\
\text { vb.) }\end{array}$ & 671 & & & \\
\hline $\begin{array}{l}\text { Et ve et ürünlerinde hile yapılması (\%100 dana eti denilen sucu- } \\
\text { ğun at veya eşek etinden ya da tavuk ve sakatattan yapılması } \\
\text { gibi) }\end{array}$ & ,642 & & & \\
\hline Tüketicinin yasal haklarının kullandırılmaması & 626 & & & \\
\hline Tüketiciye fahiş fiyatla satış yapılması & ,550 & & & \\
\hline Faktör 3 Aldatıcı ve Yanıltıcı Satış Teknikleri Kullanılması & & 1,68 & 7,0 & 55,9 \\
\hline $\begin{array}{l}\text { Pazarcıların tezgaha güzel ürünleri dizip torbaya kötü ürünleri } \\
\text { doldurması }\end{array}$ & ,728 & & & \\
\hline $\begin{array}{l}\text { Göstermelik veya aldatıcı indirimlerle müşteri çekilmeye çalışıl- } \\
\text { ması }\end{array}$ & ,728 & & & \\
\hline $\begin{array}{l}\text { Stoklarda olmayan ürünler varmış gibi davranıp müşteri çek- } \\
\text { meye çalışarak başka ürün satılmaya çalışılması }\end{array}$ & 690 & & & \\
\hline Bazı müşterilere ayrıcalıklı davranılması & 667 & & & \\
\hline $\begin{array}{l}\text { Satış esnasında satı̧̧ elamanı tarafından ürünün özelliklerinin } \\
\text { abartılı anlatılması }\end{array}$ &, 536 & & & \\
\hline İade kabul edilmemesi & 415 & & & \\
\hline Faktör 4 Aldatıcı ve Yanıltıcı Reklamlar & & 1,49 & 6,2 & 62,2 \\
\hline Satılan hizmetlerle ilgili aldatıcı ve yanıltıcı reklam yapılması, & 846 & & & \\
\hline Satılan mallarla ilgili aldatıcı ve yanıltıcı reklam yapılması & 679 & & & \\
\hline Faktör 5 Satış Elemanından Kaynaklanan Sorunlar & & 1,20 & 5,0 & 67,2 \\
\hline $\begin{array}{l}\text { Satış esnasında satış elamanı tarafından ürünün özelliklerinin ek- } \\
\text { sik anlatılması }\end{array}$ & ,752 & & & \\
\hline Tüketiciye saygısız davranılması & 592 & & & \\
\hline Tüketiciye işletme ile ilgili yalan söylenilmesi & 462 & & & \\
\hline $\mathrm{KMO}=$ & & & & ,832 \\
\hline Sig & & & &, 000 \\
\hline
\end{tabular}

Araştırma sonuçlarına göre, etik dışı algı ölçeği faktör analizi uygulanabilirliği mümkün çıkmaktadır. p<0,05. KMO 0,832 olup bire yaklaştığı için güvenilirlik düzeyi yüksektir. Sözkonusu değerlerin uygun çıkması araştırmanın faktör analizine uygunluğunu göstermiş̧ir. Araştırma kapsamında firmaların etik dışı davranışlarına ilişkin tüketici algıları 5 alt faktör grubunda ortaya çıkmıştır. Bunlar sırasıyla Satış Esnasında Yaşanılan Sorunlar, Tüketicinin Ekonomik Çıkarları, İnancı ve Sağlığı İle İlgili Sorunlar, Aldatıcı ve Yanıltıcı Satış Teknikleri Kullanılması, Aldatıcı ve Yanıltıcı Reklamlar ve Satış Elemanından Kaynaklanan Sorunlardır. Bu alt faktör grupların firmaların etik dışı davranışlarına ilişkin tüketici algısının \%67 sini açıklamaktadır. 


\section{Farklılık Testleri}

Tablo 4.Cinsiyet ve faktör alt gruplar bağımsız $t$ testi

\begin{tabular}{|c|c|c|c|c|c|c|c|}
\hline & & & & Std. & & & \\
\hline & Cinsiyet & $\mathrm{N}$ & Ortalama & Sapma & $\mathrm{t}$ & df & $\mathrm{P}$ \\
\hline \multirow[t]{2}{*}{ Satış Esnasında Yaşanılan Sorunlar } & kadın & 186 & 1,1797 & 30650 & \multirow{2}{*}{$-2,233$} & \multirow{2}{*}{403} & \multirow{2}{*}{,026 } \\
\hline & erkek & 219 & 1,2740 &, 50150 & & & \\
\hline \multirow{2}{*}{$\begin{array}{l}\text { Tüketicinin Ekonomik Çıkarları, İnancı } \\
\text { ve Sağlığı İle İlgili Sorunlar }\end{array}$} & kadın & 186 & 1,1290 & ,25543 & \multirow{2}{*}{$-1,690$} & \multirow{2}{*}{403} & \multirow{2}{*}{,092 } \\
\hline & erkek & 219 & 1,1918 & 44813 & & & \\
\hline \multirow{2}{*}{$\begin{array}{l}\text { Aldatıcı ve Yanıltııı Satış Teknikleri } \\
\text { Kullanılması }\end{array}$} & kadın & 186 & 1,6237 &, 50129 & \multirow{2}{*}{232} & \multirow{2}{*}{403} & \multirow{2}{*}{816} \\
\hline & erkek & 219 & 1,6119 &, 51510 & & & \\
\hline \multirow[t]{2}{*}{ Aldatıcı ve Yanıltıcı Reklamlar } & kadın & 186 & 1,4032 &, 55390 & \multirow{2}{*}{,111 } & \multirow{2}{*}{403} & \multirow{2}{*}{,912 } \\
\hline & erkek & 219 & 1,3973 &, 52435 & & & \\
\hline \multirow[t]{2}{*}{ Satış Elemanından Kaynaklanan Sorunlar } & kadın & 186 & 1,3118 & ,35449 & \multirow{2}{*}{$-1,019$} & \multirow{2}{*}{403} & \multirow{2}{*}{,309 } \\
\hline & erkek & 219 & 1,3562 & 49563 & & & \\
\hline
\end{tabular}

Araştırma sonuçlarına göre, etik dişı davranışlar konusunda sadece Satış Esnasında Yaşanılan Sorunlar alt faktör grubunda kadın ve erkekler arasında anlamlı farklılık görülmektedir $(\mathrm{p}<0.05)$. Buna göre kadınların ortalaması erkeklere göre anlamlı şekilde daha yüksektir. (Örneğin erkek ortalaması 1,27, Kadınların ortalaması 1,17) Yani satış esnasında yaşanılan sorunlar kadınlar tarafından erkeklere göre daha az etik dışı olarak kabul edilmiştir. Diğer faktör alt gruplarında anlamlı farklılık olmasa da ekonomik çıkarlar ile ilgili sorunlar ve satış elemanlarından kaynaklanan sorunları kadınların daha fazla etik dışı bulduğu söylenebilir. Bu nedenle kadın ve erkeklere yönelik satış politikalarında farklılıkların göz önünde bulundurulmasının faydalı olacağı söylenebilir.

Tablo 5.Yaş Değişkeni ve faktör alt gruplarn tek yönlü varyans analizi

\begin{tabular}{llll}
\hline & df & F & P \\
\hline Satış Esnasında Yaşanılan Sorunlar & 4 & 8,005 &, 000 \\
\hline Tüketicinin Ekonomik Çıkarları, İnancı ve Sağlığı İle İlgili Sorunlar & 4 & 2,253 &, 063 \\
\hline Aldatıcı ve Yanıltıcı Satış Teknikleri Kullanılması & 4 & 4,386 &, 002 \\
\hline Aldatıcı ve Yanıltıcı Reklamlar & 4 & 2,547 &, 039 \\
\hline Satış Elemanından Kaynaklanan Sorunlar & 4 & 3,631 &, 006 \\
\hline
\end{tabular}

Araştırma sonuçlarına göre, Tüketicinin Ekonomik Çıkarları, İnancı ve Sağlı̆̆ ile ilgili sorunlar alt faktör grubunun dişındaki tüm alt gruplarda anlamlı farklılık söz konusudur $\mathrm{p}<0,05$. Hangi alt gruplar arasında nasıl bir farklılık olduğu aşağıdaki tabloda gösterilmektedir. 
Tablo 6. Yaş Alt gruplan ve değişkenler arası ortalamalar

\begin{tabular}{|c|c|c|c|c|}
\hline & & $\mathrm{N}$ & Ortalama & Std. Sapma \\
\hline \multirow[t]{6}{*}{ Satış Esnasında Yaşanılan Sorunlar } & $18-25$ & 36 & 1,2262 & ,29252 \\
\hline & $26-32$ & 141 & 1,1277 & ,20751 \\
\hline & $33-40$ & 90 & 1,1762 & ,24515 \\
\hline & $41-48$ & 87 & 1,4335 & ,75324 \\
\hline & $48+$ & 51 & 1,2689 & ,30054 \\
\hline & Toplam & 405 & 1,2307 & ,42537 \\
\hline \multirow[t]{6}{*}{ Aldatıcı ve Yanıltıcı Satış Teknikleri Kullanılması } & $18-25$ & 36 & 1,7361 & ,41091 \\
\hline & $26-32$ & 141 & 1,5851 &, 50341 \\
\hline & $33-40$ & 90 & 1,4611 & 41209 \\
\hline & $41-48$ & 87 & 1,7356 & ,65076 \\
\hline & $48+$ & 51 & 1,6961 & 37521 \\
\hline & Toplam & 405 & 1,6173 &, 50821 \\
\hline \multirow[t]{6}{*}{ Aldatıcı ve Yaniltıcı Reklamlar } & $18-25$ & 36 & 1,3333 & 47809 \\
\hline & $26-32$ & 141 & 1,4149 & ,53103 \\
\hline & $33-40$ & 90 & 1,5333 & ,50168 \\
\hline & $41-48$ & 87 & 1,2931 & ,55275 \\
\hline & $48+$ & 51 & 1,3529 & ,59409 \\
\hline & Toplam & 405 & 1,4000 & ,53746 \\
\hline \multirow[t]{6}{*}{ Satış Elemanından Kaynaklanan Sorunlar } & $18-25$ & 36 & 1,3889 & ,53154 \\
\hline & $26-32$ & 141 & 1,3404 & ,43910 \\
\hline & $33-40$ & 90 & 1,2889 & ,27002 \\
\hline & $41-48$ & 87 & 1,4483 & ,57247 \\
\hline & $48+$ & 51 & 1,1765 & ,23431 \\
\hline & Toplam & 405 & 1,3358 & ,43656 \\
\hline
\end{tabular}

Araştırma sonuçlarına göre, satış esnasında yaşanılan sorunları 26-32 yaş arası katılımcılar diğer yaş gruplarına göre daha fazla etik dışı bulmaktadır. $\mathrm{Bu}$ yaş grubunun satış esnasını diğer yaş gruplarına göre daha fazla etik dışı bulduğu ortaya çıkmaktadır. Aldatıı ve Yanıltıcı Satış Teknikleri Kullanılması alt faktör grubunda ise 18-25, 41-48 ve 48 yaş üzerinde ki grubun diğer yaş gruplarına göre daha az etik dışı algılarının olduğu görülmektedir. Aldatıcı ve Yanıltıcı Reklamların etik dışılığı konusunda 41-48 ve 18-25 yaş gruplarının daha fazla etik dışı kabulü söz konusudur. Buna göre bu yaş gruplarının reklam algı duyarlılığı diğer yaş gruplarına göre daha fazladır. Satış Elemanından Kaynaklanan Sorunların etik dışı kabul edilmesi 48 yaş üzeri grubunda diğer yaş gruplarına göre daha yüksek çıkmaktadır. Buna göre bu yaş grubu tüketicilerin satış elemanları konusunda daha hassas oldukları söylenebilmektedir. 
Tablo 7. Eğitim Değişkeni ve faktör alt gruplarn tek yönlü varyans analizi

\begin{tabular}{llll}
\hline & $\mathrm{df}$ & $\mathrm{F}$ & $\mathrm{P}$ \\
\hline Satış Esnasında Yaşanılan Sorunlar & 4 & 1,235 &, 296 \\
\hline Tüketicinin Ekonomik Çıkarları, İnancı ve Sağlı̆̆ı İle İlgili Sorunlar & 4 & 3,104 &, 016 \\
\hline Aldatıcı ve Yanıltıcı Satış Teknikleri Kullanılması & 4 & 3,265 &, 012 \\
\hline Aldatıcı ve Yanıltıcı Reklamlar & 4 & 4,947 &, 001 \\
\hline Satış Elemanından Kaynaklanan Sorunlar & 4 &, 673 &, 611 \\
\hline
\end{tabular}

Araştırma sonuçlarına göre, eğitim düzeyi ve etik dışı algı karşılaştırmasında, Tüketicinin Ekonomik Çıkarları, İnancı ve Sağlığı İle İlgili Sorunlar, Aldatıcı ve Yanıltıcı Satış Teknikleri Kullanılması, Aldatıcı ve Yanıltıcı Reklamlar alt faktör grupları eğitim düzeyine göre anlamlı farklılık göstermektedir $p<0,05$. Eğitim düzeylerine göre farklılıklar aşağıda tabloda gösterilmiştir.

Tablo 8. Eğitim Alt gruplan ve değişkenler arası ortalamalar

\begin{tabular}{|c|c|c|c|c|}
\hline & & $\mathrm{N}$ & Ortalama & Std. Sapma \\
\hline \multirow{6}{*}{$\begin{array}{l}\text { Tüketicinin Ekonomik Çıkarları, } \\
\text { İnancı ve Sağlığı } \\
\text { İle İlgili Sorunlar }\end{array}$} & ilköğretim & 21 & 1,0000 & 00000 \\
\hline & lise & 60 & 1,2167 & 41545 \\
\hline & önlisans & 30 & 1,3333 & ,52523 \\
\hline & lisans & 237 & 1,1435 & ,38578 \\
\hline & lisansüstü & 57 & 1,1579 & ,14914 \\
\hline & Toplam & 405 & 1,1630 & ,37312 \\
\hline \multirow{6}{*}{$\begin{array}{l}\text { Aldatıcı ve Yanıltıcı Satış Teknikleri } \\
\text { Kullanılması }\end{array}$} & ilköğretim & 21 & 1,2619 & 48181 \\
\hline & lise & 60 & 1,6583 & ,56866 \\
\hline & önlisans & 30 & 1,7333 & ,73187 \\
\hline & lisans & 237 & 1,6329 & 46969 \\
\hline & lisansüstü & 57 & 1,5789 & 41679 \\
\hline & Toplam & 405 & 1,6173 & ,50821 \\
\hline \multirow[t]{6}{*}{ Aldatıcı ve Yanıltıcı Reklamlar } & ilköğretim & 21 & 1,0000 & , 00000 \\
\hline & lise & 60 & 1,4500 & ,59447 \\
\hline & önlisans & 30 & 1,2500 & ,52111 \\
\hline & lisans & 237 & 1,4620 & ,54523 \\
\hline & lisansüstü & 57 & 1,3158 & ,46896 \\
\hline & Toplam & 405 & 1,4000 & ,53746 \\
\hline
\end{tabular}

Araştırma sonuçlarına göre, Tüketicinin Ekonomik Çıkarları, İnancı ve Sağlığı İle İlgili Sorunlar alt faktör grubunda eğitim düzeyi yükseldikçe etik dışı algısı azalmaktadır. Buna göre ekonomik çıkar ve sağlıkla ilgili sorunlarda eğitim düzeyi arttıkça etik dışı davranış algısı göreceli olarak azalmaktadır. Aldatıcı ve Yanıltııı Satış Teknikleri Kullanılmasının etik dışı algılanmasının ön lisans ve lisans düzeyinde diğer eğitim gruplarına göre daha düşük olduğu ortaya çımaktadır. Buna göre ön lisans ve lisans eğitim seviyesi diğer eğitim düzeylerine göre aldatıcı satış tekniklerine karşı duyarlılıkları 
daha düşük olmaktadır. Aldatıcı ve Yanıltıcı Reklamların etik dışı kabul edilme algısının lise ve lisans eğitim mezunlarında diğer eğitim gruplarına göre daha düşük olduğu belirlenmiştir.

Tablo 9.Gelir Değişkeni ve faktör alt gruplan tek yönlü varyans analizi

\begin{tabular}{llll}
\hline & $\mathrm{df}$ & $\mathrm{F}$ & $\mathrm{P}$ \\
\hline Satış Esnasında Yaşanılan Sorunlar & 3 &, 892 &, 445 \\
\hline Tüketicinin Ekonomik Çıkarları, İnancı ve Sağlı̆̆ı İle İlgili Sorunlar & 3 & 1,402 &, 242 \\
\hline Aldatıcı ve Yanıltıcı Satış Teknikleri Kullanılması & 3 & 7,647 &, 000 \\
\hline Aldatıcı ve Yanıltıcı Reklamlar & 3 & 1,854 &, 137 \\
\hline Satış Elemanından Kaynaklanan Sorunlar & 3 & 3,449 &, 017 \\
\hline
\end{tabular}

Araştırma sonuçlarına göre gelir değişkeni ile etik dışı davranış algısı karşılaştırmasında Aldatıcı ve Yanıltııı Satış Teknikleri Kullanılması ve Satış Elemanından Kaynaklanan Sorunlar alt grupları anlamlı farklılık gösterirken $\mathrm{p}<0,05$ diğer alt gruplarda anlamlı farklılık söz konusu olmamıştır. Anlamlı farklılık gösteren alt grupların hangi gelir alt gruplarında farklılık gösterdiği aşağıdaki tabloda gösterilmektedir.

Tablo 10. Gelir Alt grupları ve değişkenler arası ortalamalar

\begin{tabular}{lllll}
\hline & & $\mathrm{N}$ & Ortalama & Std. Sapma \\
\hline Aldatıcı ve Yanıltıcı Satış & $0-1000$ & 27 & 1,2407 &, 27863 \\
\cline { 2 - 5 } Teknikleri Kullanılması & $1001-2000$ & 54 & 1,6852 &, 56604 \\
\cline { 2 - 5 } & $2001-3000$ & 84 & 1,7500 &, 58855 \\
\cline { 2 - 5 } & 3001 ve üzeri & 240 & 1,5979 &, 46171 \\
\cline { 2 - 5 } & Toplam & 405 & 1,6173 &, 50821 \\
\hline Satış Elemanından & $0-1000$ & 27 & 1,1111 &, 22646 \\
\cline { 2 - 5 } & $1001-2000$ & 54 & 1,3519 &, 30658 \\
\cline { 2 - 5 } & $2001-3000$ & 84 & 1,4167 &, 48780 \\
\cline { 2 - 4 } & 3001 ve üzeri & 240 & 1,3292 &, 45277 \\
\cline { 2 - 4 } & Toplam & 405 & 1,3358 &, 43656 \\
\hline
\end{tabular}

Araştırma sonuçlarına göre, etik dışı davranış algısı konusunda Aldatıcı ve Yanıltıcı Satış Teknikleri Kullanılması alt faktör grubunda 1001 ve 3000 arasında ki gelir grubunun diğer gelir gruplarına göre anlamlı farklılık gösterdiği ve bu alt faktör grubunu diğer gelir gruplarına göre daha az etik dış1 bulduğu ortaya çıkmıştır. Satış Elemanından Kaynaklanan Sorunlar alt faktör grubunda ise 2001-3000 TL gelir grubunun etik dışı algısı diğer gelir gruplarına göre daha düşük çıkmıştır. 


\section{Sonuç ve Öneriler}

Pazarlama karar ve uygulamalarında ahlaki yaklaşımın geçerli kılınması noktasında, kişisel özellikler, organizasyonel farklılıklar ve toplumsal ahlaki ve kültürel değerlere uygun bir çerçevenin oluşturulmasında yarar vardır. Böyle bir çerçevede pazarlamacıların kişisel ahlaki değerleri, tecrübeleri ve kurumsal ahlaki değerler, pazarlama ahlakının uygulama ve denetiminde belirleyici olurlar.

Tüketicilerin iş etiğine yani işletmelerdeki etik dışı davranışlara bakış açılarının ele alındığı araştırmada, Ankara ili sınırları içinde 405 cevaplayıcı ile görüşülmüştür. Nihai değişken seti dört faktör altında toplanarak tüketicilerin iş etiğine ilişkin tutumlarını açıklamaya yönelik bir yaklaşım sağlanmıştır. Tüketicilerin iş etiğine yönelik tutumlarını temsil eden faktörler açıklanmaya çalışılmıştır.

Araştırma sonuçlarına göre, işletmelerdeki etik dışı davranışların tüketicilerin alışveriş tercihinde son derece önemli olduğu ortaya çıkmıştır. Tüketiciler açısından en etik dışı bulunan konu 1,0667 ortalama ile Et ve et ürünlerinde hile yapılmasıdır. (\%100 dana eti denilen sucuğun at veya eşek etinden ya da tavuk ve sakatattan yapılması gibi). Bu veri de bize tüketicilerin gıda konusunda oldukça hassas olduklarını göstermektedir. İkinci sırada etik dışı bulunan konuysa 1,1333 oranı ile "İnsan sağlığı açısından güvenli olmayan ürünlerin satılması" ve "Ölçü ve tartıda hile yapılması" çıkıştır. Üçüncü sırada etik dışı bulunan hususlar ise 1,1407 oranı ile "Gıdada toplumun dini hassasiyetlerine aykın katkıların kullanılması ve bunun satış anında bildirilmemesi (domuz jelatini, alkol vb.)" ve "Daha fazla kar elde etmek için sağlığa zararlı ürünler satılması" olarak belirtilmiştir.

Daha az etik dışı bulunan konulara bakacak olursak; ilk sırada 1,9185 oranı ile Bazı müşterilere aynıcalıklı davranılması gelmektedir. İade kabul edilmemesi de 1,7111 oranı ile daha az etik dışı bulunan konulardan ikinci sırayı almaktadır. Üçüncü sırada ise "Göstermelik veya aldatıcı indirimlerle müşteri çekilmeye çalışılması" gelmektedir. Bu nedenle özellikle perakende sektöründe tüketiciye mal ve hizmet sunan firmaların pazarda kalıcı hale gelmek ve pazar payını artırmak için çalışanlarını etik dışı davranışlar konusunda eğitmesi, satılan mal ve hizmet hakkında aldatıcı ve yanıltıı bilgi ver- 
melerinin önüne geçilmesi, tüketicilerin dini inançlarına aykırı mallar konusunda hassasiyet göstermeleri ve pazarlama stratejilerini geliştirirken bu konuları da ciddi şekilde ele alması faydalı olacaktır.

Araştırma sonuçlarına göre, etik dışı algı ölçeği faktör analizi uygulanabilirliği mümkün çıkmaktadır. p<0,05. KMO 0,832 olup bire yaklaştığı için güvenilirlik düzeyi yüksektir. Söz konusu değerlerin uygun çıkması araştırmanın faktör analizine uygunluğunu göstermiştir. Araştırma kapsamında firmaların etik dışı davranışlarına ilişkin tüketici algıları 5 alt faktör grubunda ortaya çıkmıştır. Bunlar sırasıyla "Satış Esnasında Yaşanılan Sorunlar, Tüketicinin Ekonomik Çıkarları, İnancı ve Sağlığı İle İlgili Sorunlar, Aldatıcı ve Yanıltııı Satış Teknikleri Kullanılması, Aldatıcı ve Yanıltıcı Reklamlar ve Satış Elemanından Kaynaklanan" sorunlardır. Bu alt faktör grupların firmaların etik dışı davranışlarına ilişkin tüketici algısında varyansın \% 67 sini açıklamaktadır.

Etik dışı davranışlar konusunda sadece satış esnasında yaşanılan sorunlar alt faktör grubunda kadın ve erkekler arasında anlamlı farklılık görülmekte$\operatorname{dir}(\mathrm{p}<0.05)$. Buna göre kadınların ortalaması erkeklere göre anlamlı şekilde daha yüksektir. Yani satış esnasında yaşanılan sorunlar kadınlar tarafından erkeklere göre daha az etik dışı olarak kabul edilmiştir. Diğer faktör alt gruplarında anlamlı farklılık olmasa da ekonomik çıkarlar ile ilgili sorunlar ve satış elemanlarından kaynaklanan sorunları kadınların daha fazla etik dışı bulduğu söylenebilir. Bu nedenle kadın ve erkeklere yönelik satış politikalarında farklılıkların göz önünde bulundurulmasının faydalı olacağı söylenebilir.

Tüketicinin Ekonomik Çıkarları, İnancı ve Sağlığı ile ilgili sorunlar alt faktör grubunun dışındaki tüm alt gruplarda anlamlı farklılık söz konusudur $p<0,05$. satış esnasında yaşanılan sorunları 26-32 yaş arası katılımcılar diğer yaş gruplarına göre daha fazla etik dışı bulmaktadır. Bu yaş grubunun satış esnasını diğer yaş gruplarına göre daha fazla etik dışı bulduğu ortaya çıkmaktadır. Aldatıcı ve Yanıltıı Satış Teknikleri Kullanılması alt faktör grubunda ise 18-25, 41-48 ve 48 yaş üzerinde ki grubun diğer yaş gruplarına göre daha az etik dışı algılarının olduğu görülmektedir. Aldatıcı ve Yanıltıcı Reklamların etik dışılığı konusunda 41-48 ve 18-25 yaş gruplarının daha fazla etik dışı kabulü söz konusudur. Buna göre bu yaş gruplarının reklam algı duyarlılığı diğer yaş gruplarına göre daha fazladır. Satış Elemanından Kaynakla- 
nan Sorunların etik dışı kabul edilmesi 48 yaş üzeri grubunda diğer yaş gruplarına göre daha yüksek çıkmaktadır. Buna göre bu yaş grubu tüketicilerin satış elemanları konusunda daha hassas oldukları söylenebilmektedir.

Eğitim düzeyi ve etik dışı algı karşılaştırmasında, Tüketicinin Ekonomik Çıkarları, İnancı ve Sağlığı İle İlgili Sorunlar, Aldatıcı ve Yanıltıı Satış Teknikleri Kullanılması, Aldatıcı ve Yanıltıc Reklamlar alt faktör grupları eğitim düzeyine göre anlamlı farklılık göstermektedir $\mathrm{p}<0,05$. Tüketicinin Ekonomik Çıkarları, İnancı ve Sağlığı İle İlgili Sorunlar alt faktör grubunda eğitim düzeyi yükseldikçe etik dışı algısı azalmaktadır. Buna göre ekonomik çıkar ve sağlıkla ilgili sorunlarda eğitim düzeyi arttıkça etik dışı davranış algısı göreceli olarak azalmaktadır. Aldatıcı ve Yanıltıcı Satış Teknikleri Kullanılmasının etik dışı algılanmasının önlisans ve lisans düzeyinde diğer eğitim gruplarına göre daha düşük olduğu ortaya çıkmaktadır. Buna göre önlisans ve lisans eğitim seviyesi diğer eğitim düzeylerine göre aldatıcı satış tekniklerine karşı duyarlılıkları daha düşük olmaktadır. Aldatıcı ve Yanıltıcı Reklamların etik dışı kabul edilme algısının lise ve lisans eğitim mezunlarında diğer eğitim gruplarına göre daha düşük olduğu belirlenmiştir.

Gelir değişkeni ile etik dışı davranış algısı karşılaştırmasında Aldatıcı ve Yanıltııı Satış Teknikleri Kullanılması ve Satış Elemanından Kaynaklanan Sorunlar alt grupları anlamlı farklılık gösterirken $p<0,05$ diğer alt gruplarda anlamlı farklılık söz konusu olmamıştır. Aldatıcı ve Yanıltıcı Satış Teknikleri Kullanılması alt faktör grubunda 1001 ve 3000 arasında ki gelir grubunun diğer gelir gruplarına göre anlamlı farklılık gösterdiği ve bu alt faktör grubunu diğer gelir gruplarına göre daha az etik dışı bulduğu ortaya çıkmıştır. Satış Elemanından Kaynaklanan Sorunlar alt faktör grubunda ise 2001-3000 TL gelir grubunun etik dışı algısı diğer gelir gruplarına göre daha düşük çıkmıştır.

Sonuç olarak tüketicilerin işletmelerin etik dışı davranışlarından rahatsızlık duyduğu, bu konuda farkındalıklarının olduğu ancak yukarıda belirtildiği gibi bazılarını görmezden gelip bazılarına tepki verdikleri anlaşılmaktadır. Et ve et ürünlerinde hile yapılması, İnsan sağlı̆̆ açısından güvenli olmayan ürünlerin satılması, ölçü ve tartıda hile yapılması, gıdada toplumun dini hassasiyetlerine aykırı katkıların kullanılması ve bunun satış anında bildirilmemesi (domuz jelatini, alkol vb.) ve daha fazla kar elde etmek için sağlığa zararlı ürünler satılması gibi konularda hassas oldukları ortaya çıkmıştır. İ̧sletmelerin müşteri memnuniyetini sağlayarak pazarda kalııı hale gelebilmek için bu hususlara dikkat etmeleri faydalı olacaktır. 


\section{EXTENDED ABSTRACT}

\section{A Field Study on Consumers' Evaluations About Businesses' Unethical Behaviors \\ * \\ Yakup Güzel \\ Hacettepe University}

When the studies related to work ethics are reviewed, it is seen that work ethic is perceived as internal matter of businesses in general; therefore, it is more focused on work ethics of the personnel in that businesses. However, work ethics is directly related to corporate image of business and especially have importance with regards to businesses' stakeholders. One of them most important stakeholders of business is consumer and in terms of consumer to what degree honesty and reliability of business or brand is important? When we consider the relationship between business and consumer, we realize that studies are more on work ethics and consumer ethic. There is need for a comprehensive work towards the impact of work ethics on consumer behavior and ethic standards within business- consumer relations.

In this scope, with the aim of identifying that how unethical behaviors in businesses providing goods and services to consumers are evaluated by consumers, in the study, the ethical evaluation of complaints of consumers over the 18 age and residing in Ankara, in consumer perception are examined as field research in December 2019. Each and every complaint and their frequency rates are obtained from field research data. The ethical evaluation of that complaints are also tried to be uncovered through asking to consumers. In this way, with regards to customer satisfcation which type of behaviors that businesses need to avoid could be find out.

The study aims at analyzing ethical evaluations in consumers' perception in terms of business complaints from consumers who live in Ankara, through a field analysis.

The study results reveal that unethical behaviors of businesses are decisive for consumers' shopping preferences. The most unethical issue for consumers is cheating on meat and processed meat products, by the average of 1,0667.

The second unethical issue for consumers is "marketing products that are unsafe for human health" and "cheating on meausurement and weighing." 
by the average of 1,1333 . The third place is shared by "usage of additives that are contrary to religious sensibilities of the community in food and refusing to inform consumers on these practices at the time of sale (foods containing pork gelatin or alcohol)" and "marketing products that are harmful to health in order to gain more profit", by the average of 1,1407.

The less unethical issues that the study found are "privileged treatment for some consumers", by the average of 1,9185 , and "refusing to accept consumers' returns" by the average of 1,7111 . The issue that takes the third place in this category is "attracting consumers' attention with false and misleading discount claims". Accordingly, it will be useful for companies offering products and services to consumers in retail sector to train their employees on unethical behaviors to become permanent and to raise their market share, and to show sensibility on products that are contrary to consumers' religious beliefs. It will be equally useful to prevent companies to give deceptive and misleading information to consumers

Consequently, it is understood that consumers are disturbed by companies' unethical behaviors and they have awareness in this issue. However, consumers may react to some of these behaviours while they ignore some of them, as mentioned above. The study also shows that consumers have sensibilities on certain issues such as cheating on meat and processed meat products, marketing products that are unsafe to human health, cheating on meausurement and weighing, usage of additives that are contrary to religious sensibilities of the community in food and avoiding notifying this practices at the time of sale (foods containing pork gelatin or alcohol) and marketing products that are harmful to health in order to gain more profit. In order to promote customer satisfaction and to become permanent in the market, it will be beneficial for all businesses to pay attention to these issues.

\section{Kaynakça / References}

Akbulut, E. E. (2000). Etik davranış kurallan ve Türkiye Sermaye Piyasası aracı kuruluşlan için öneri. Ankara: Sermaye Piyasası Kurulu Yayını. 25.08.2007 tarihinde http://www.spk.gov.tr/yayinlar/kye/2000_eebruakbulut.pdf adresinden erişilmiştir.

Anadolu Ajansı. (2011). Alkolsüz içecekler. 15.02.2021 tarihinde https://www.aa.com.tr/uploads/userFiles/c09e217d-a61f-47f8-a355ddf8004cfef9/taklit-tagsis-17-nisan-2022.pdf adresinden erişilmiştir. 
İstanbul Üniversitesi (2020). İstanbul Üniversitesi Açık Ve Uzaktan Eğitim Fakültesi 2019-2020 ders kitapları. 15.02.2021 tarihinde http://auzefkitap.istanbul.edu.tr/ adresinden erişilmiştir.

Aslan, M. (2005). İş ve meslek ahlakı. Ankara: Siyasal Kitapevi. s.154.

Blanchard, K. (2002). Değerlerle yönetim. Executive Excellence Dergisi, 64, 22-23.

Ettenson, R. ve Gaeth, G. (1991). Commentary consumer perceptions of hybrit (bi-naitonal products. TheJournal of Consumer Marketing, 8(4), 13-18.

Gök, S . (2010). Çalışma yaşammda iş etiği: Bir alan araştırması . Journal of Social Policy Conferences, 57 ,549-577. https://dergipark.org.tr/tr/pub/iusskd/issue/885/9843 adresinden erişilmiştir.

Güler Y.B. (2014). Perakendecilik sektöründe işletme ve müssteri pazarlama etik bakış açlarının karşılaştırlması. Selçuk Üniversitesi Sosyal Bilimler Enstitüsü Dergisi, $31,65-75$.

Kurtuluş, B. (2005). İş ahlakı: Geçmişte ve günümüzde. Sosyal Siyaset Konferanslan Dergisi, 50, 737, 759 .

Office Of FairTrading. (t.y). Cookies on gov.uk. 02.07.2020 tarihinde https://www.gov.uk/government/organisations/office-of-fair-trading adresinden erişilmiştir.

Osthaus, C, R. (2004). The work ethic of the plain folk: Laborand religion in the Old South. The Journal of Southern History, 70(4), 745-782.

Özçelik, D.G. ve Torlak, Ö. (2011). Marka kişiliği algısı ile etnosentrik eğilimler arasındaki ilişki: Lewis Mavi Jeans üzerine bir araştırma. Ege Akademik Bakış, 11(3), 361-377.

Özdoğan. B. (2006). Tüketicilerin işletmelerin etik dışı pazarlama davranışların değerlendirmelerine yönelik bir alan araştrrması. Doktora Tezi, Gazi Üniversitesi, Sosyal Bilimler Enstitüsü, İşletme Anabilim Dall, 370.

Vitell, SJ. ve Ho, F.N.(1997). Ethical decision making in marketing: A synthesis and evaluation of scales measuring the various components of decision making in ethical situations. Journal of Business Ethics

\section{Kaynakça Bilgisi / Citation Information}

Güzel, Y. (2021). İşletmelerin etik dışı davranışlarının tüketiciler tarafından değerlendirilmesine yönelik bir alan araştırması. OPUS-Uluslararası Toplum Araştırmaları Dergisi, 17(35), 2082-2101. DOI: 10.26466/opus.763786 